\title{
Satellite Image Used to Solve the Impact of Silt and Velocity on Discharge Carrying Capacity of Right Bank Canals of SukkurBarrage Pakistan
}

\author{
Farhan Hussain Wagan ${ }^{1, ~ *, ~ S a d a f ~} \mathrm{Sh}^{2}$, Ghulam Hussain Wagan ${ }^{2}$ \\ ${ }^{1}$ Irrigation Department Sindh, Karachi, Pakistan \\ ${ }^{2}$ Civil Engineering, Swedish Engineering College, Rahim Yar Khan, Pakistan
}

Email address:

farhan_hussain_4u@yahoo.com (F. H. Wagan)

${ }^{*}$ Corresponding author

To cite this article:

Farhan Hussain Wagan, Sadaf She, Ghulam Hussain Wagan. Satellite Image Used to Solve the Impact of Silt and Velocity on Discharge Carrying Capacity of Right Bank Canals of SukkurBarrage Pakistan. Science Journal of Circuits, Systems and Signal Processing. Vol. 8, No. 2, 2019, pp. 40-46. doi: 10.11648/j.cssp.20190802.12

Received: June 21, 2019; Accepted: August 3, 2019; Published: August 15, 2019

\begin{abstract}
Pakistan is basically an agricultural country, agriculture is considered the back bone of the country. It helps country in earning foreign exchange, about $90 \%$ of output comes from agriculture, supports in employment and economy by exporting food grains. Luckly Pakistan has worlds third giant irrigation system, it comprises best storage infra-structure, controlling system of barrages, regulators, conveyance system of canals and an efficient drainage system both horizontal and vertical. Indus river basin irrigation system has three major reservoirs, sixteen barrages, two head works, two siphons across major rivers, 12 inter river link canals and 44 irrigation canals. Average gradient was observed from sea level as flat with rate of $12.5 \mathrm{~cm} / \mathrm{km}$ (eight inches/mile), Indus provides irrigation system to major portion of Sindh almost 41 percent. The total Gross Commanded area of Sindh and Baluchistan which depends on Indus is 5.92 Mha whereas, the only Cultivable command Area is 5.43 Mha. The major crops grown in Sindh are rice in Kharif and wheat in Rabi. Besides this, Sindh also produces horticultural crops such as: mangoes, bananas, dates and chilies. Sindh has also diversion capacity of 111 billion cubic meter (BCM) which is equivalent to 90 million Acre Feet (MAF). It was found in the research that excess of silt in Right Bank Canal is more to reduce the velocity of water. Satellite image based model shows negligible velocity to Right Pocket at Sukkur Barrage. $60 \%$ less cultivation in 2018 at SaifullahMagsi Branch Division at border of Sindh-Balochistan.
\end{abstract}

Keywords: IRIS of Pakistan, Barrage, Model, Data, Silt, Analysis, Results and Suggestions

\section{Aim and Object of Research}

Aim of this research paper is to highlight the problem related to Right Bank Region of Sukkur barrage Pakistan and its habitants specially end users. This research is to know the main problem of water shortage in right side of sukkur barrage and to solve the problem by generating model through computer.

\subsection{Area of Study}

Our area of study is sukkur barrage and Right bank canals which are badly affected due to silt deposition at right pocket of sukkur barrage.

\subsection{Climate}

We can reduce our own carbon footprint by following a few easy steps. Make conserving energy a part of your daily routine and your decisions as a consumer. When you shop for new appliances like refrigerators, washers, and dryers, look for products with the government's Energy Star label; they meet a higher standard for energy efficiency than the minimum federal requirements. When you buy a car, look for one with the highest gas mileage and lowest emissions. You can also reduce your emissions by taking public transportation or carpooling when possible. And while new federal and state standards are a step in the right direction, much more needs to be done. Voice your support of climate-friendly and climate 
change preparedness policies, and tell your representatives that transitioning from dirty fossil fuels to clean power should be a top priority-because it's vital to building healthy, more secure communities. [1]

\subsection{Waterability of the Indus Basin Irrigation System}

There are three main sources of water availability in the Indus basin.

The average annual flow of western rivers of Indus basin is approximately 142 million acres feet MAF. About 104 MAF of this water is diverted for irrigation purposes and about 35 million acre feet outflows to the Arabian sea.

Another source of water is the rainfall. Irrigated areas of Indus basin receive on average 40 million acres feet of water annually. Rainfall of Sindh province is 100 to $180 \mathrm{~mm}$ per year and evaporation rate is between 1000 to $2000 \mathrm{~mm}$.

The third source of water is the groundwater. It provides approximately 40 percent of crop water requirements of the country [2].

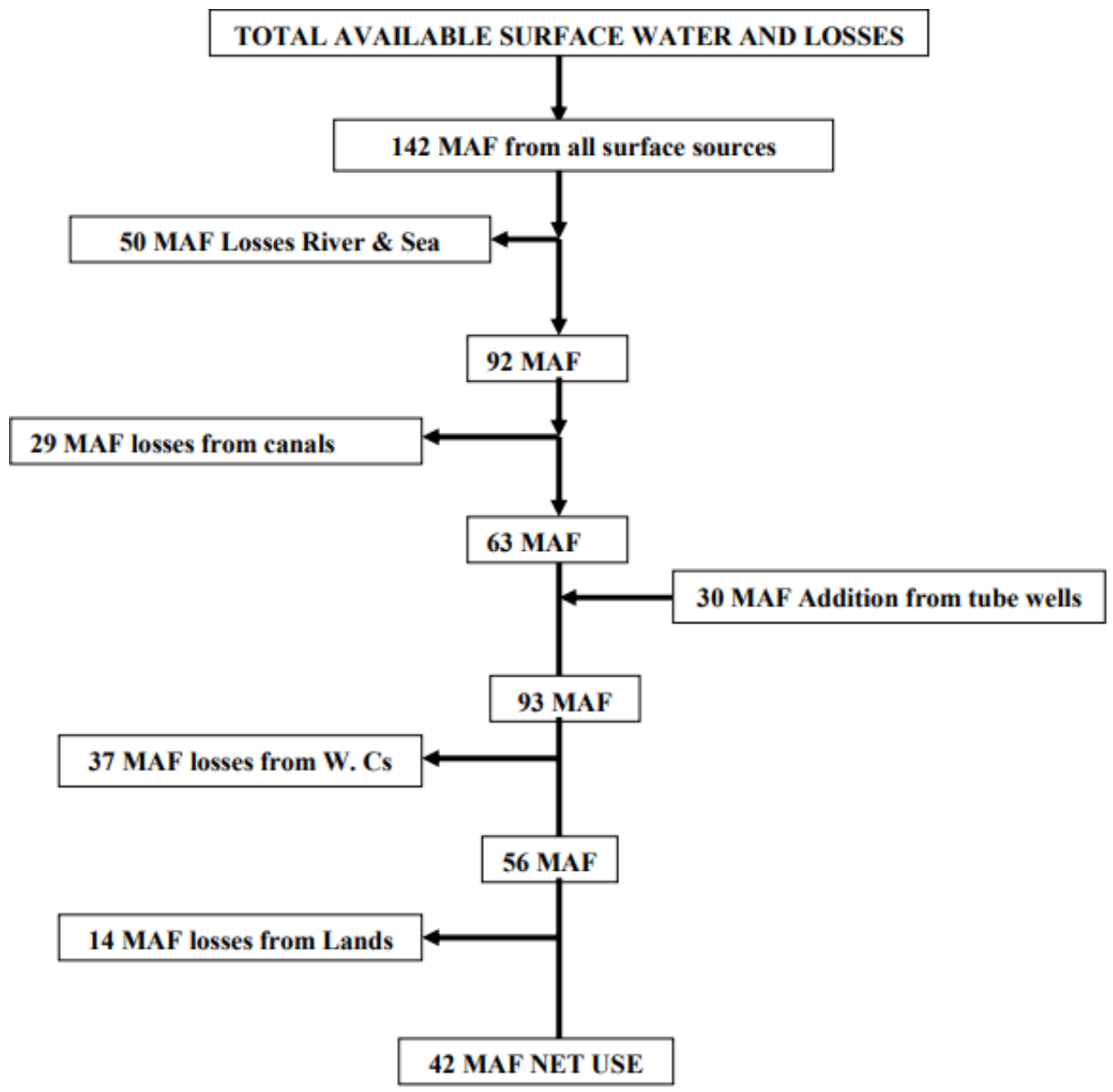

Figure 1. Flow Chart shows Total Available surface water and its losses [3].

\section{Steps for Model Generation in Computer Based Program}

1) River geometry through DEM (Digital Elevation Model).

2) Exploring RAS geometry to HEC RAS.

3) Check for corrections in HEC RAS.
4) Mesh Generation.

5) Levees formation.

6) ImbeddingBarrage model.

7) Installing Gates in Barrage.

8) Applying Flow area boundary conditions.

9) Run Program.

10)Results.

Table 1. Shows data required for HEC RAS software.

\begin{tabular}{|c|c|c|}
\hline Data Type & Specification & Source \\
\hline Digital Surface Model (DSM) & "ALOS World 3D - 30m" & JAXA \\
\hline MODIS Data & Daily MODIS terra data (june-Dec2010) for extraction of daily flood extents & NASA \\
\hline Discharge data & Daily discharge data of Sukkur barrage & Sukkur Barrage Control Room \\
\hline Levees alignment & Vector data & Sindh Irrigation Pakistan \\
\hline Architectural Models & Structure Design \& Drawings of Sukkur barrage & Sukkur Barrage Office \\
\hline
\end{tabular}




\section{Silt Deposition}

It is well known that precipitation and fresh water resources are not homogeniously distributed either spatially or temporally [4]. The main cause of silt deposition at head works and radiating canals is the reverse to natural surface and sub-surface gradient. That impacts the design discharge carrying capacity of the canals, with the passage of time and distance the velocity reduces and results in droping the sediment. According to irrigation rule, the sediment entering at head works must remain in suspension but this depends upon the velocity [5]. Dripline flushing is a maintanance procedure that is recommended for all micro irrigation systems. However flushing velocity and flushing duration which particularly affect the design and management of sub surface drip irrigation system have not been studied extensively [6]. Minimum velocities for the suspension of fine sediment in the green river canal [7]. The canal flows through dry and troppical area, The dry winds more sediment fine particles from outside intothe canal and with this sediment charge is increased, it further reduces the flow velocity. Sediment of canalsis a big problem where the feeding rivers contain a large amount of sediments [8]. The canal is alluvial and totally in filling, because of loose soil, the scouring takes place in both bed and sides, that further enhancing the sediment charge. Water flow and sediment process have been significantly erratic at the chokwe irrigation sheme and have affected its hydraulic performance [9].

\subsection{Density Formula}

The sediment load values are in tonnes. to calculate the volume of silt deposition at structure we are using calculation through density formula to determine the volume:

$$
\begin{aligned}
& \text { density = mass / volume } \\
& \text { so; volume = mass/ density }
\end{aligned}
$$

\subsection{Renard Equation}

There is a certain diversity of openion among authors certaining the distribution of water velocities and their statements regarding velocities near periphery of canal lack the precision required for ecological studies [10]. The Renard's equation predicts the sediment yield for a semi arid watershed by simulating individual hydrographs and computing sediment yield for the estimated hydraulic conditions [11-12]. sediment yield is related to the drainage area by following equation:

Formula:

$$
Y=0.001846 A^{0.1187}
$$

where: $\mathrm{Y}$ is average annual sediment yield (ac-ft/ac/yr).

$$
A=\text { Structural (watershed) area in acres. }
$$

Sediment sluicing flow factor of last 50 years was between a minimum 0.18 to a maximum 1.54 except flood months (July-Sept) which is always less than 2.0. Thus sediment shoals were developed at upstream of the Barrage.

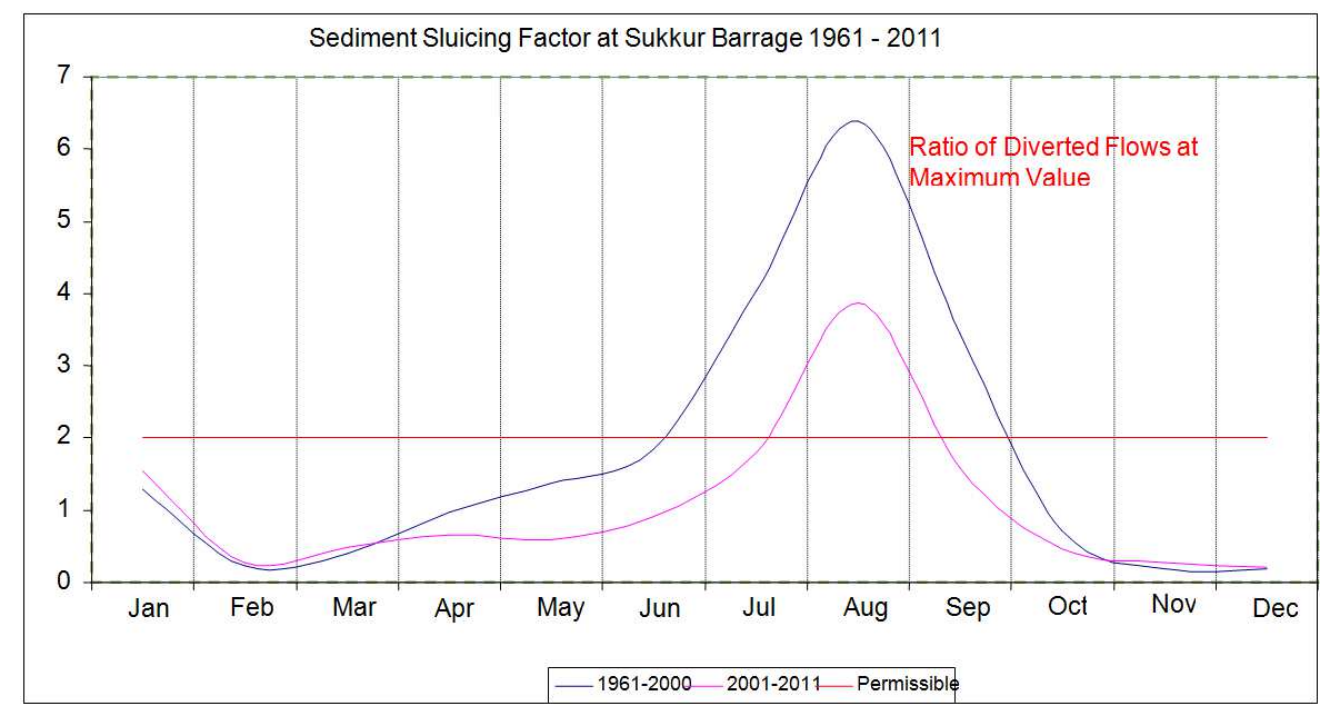

Figure 2. Shows changing river morphology and depositing of Sediments during different months creates a variety of problems such as raising of stream bed, increasing flood height along the river embankments and extended lag time from Sukkur Barrage to Kotri Barrage (i.e. 300 miles reach).

\section{Sukkur Barrage}

Sukkur Barrage has network based on seven canals (9923 km) 6166 miles long, feeding the largest irrigation system in the world, with more than 7.63 million acres of irrigated land which is approximately 25 percent of total canal irrigated area of the country. Structure of barrage is based on 66 spans, each 60 feet and weighing 50 tons. Figure shows Sukkur barrage during Flood 2010. Goal of research study is to present a hypothetical flood in Indus River at point of Sukkur barrage with potential changes in geometry of river in premises of Sukkur barrage. 


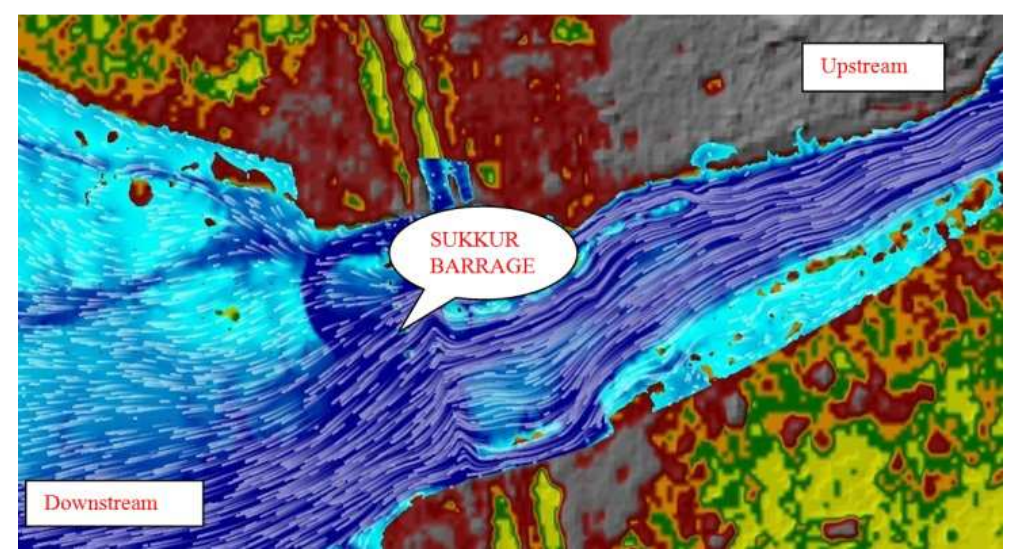

Figure 3. Shows impact of water particle tracing from gates of barrage.

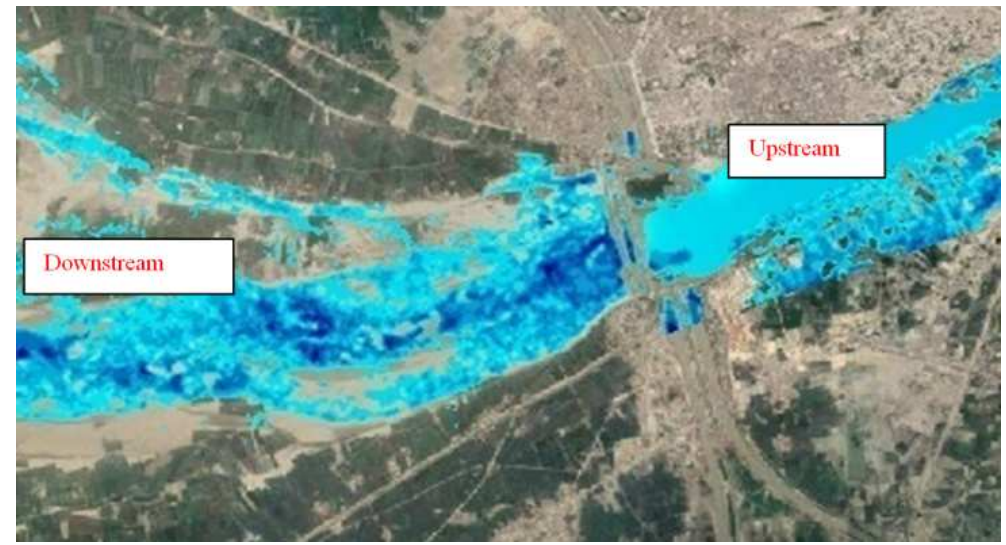

Figure 4. Model shows negligible velocity to Right Pocket at Sukkur Barrage.

\section{Problem Statement}

1) Excessive silt entry in right bank canals.

2) Sand dunes formed in front of head regulators inside right pocket.

3) Right Bank canals not able to take the design discharge.

4) Models studies carried out in Puna in from 1935 to 1942 to rectify the problem.

5) Recommendations of Model study implemented by 1942.

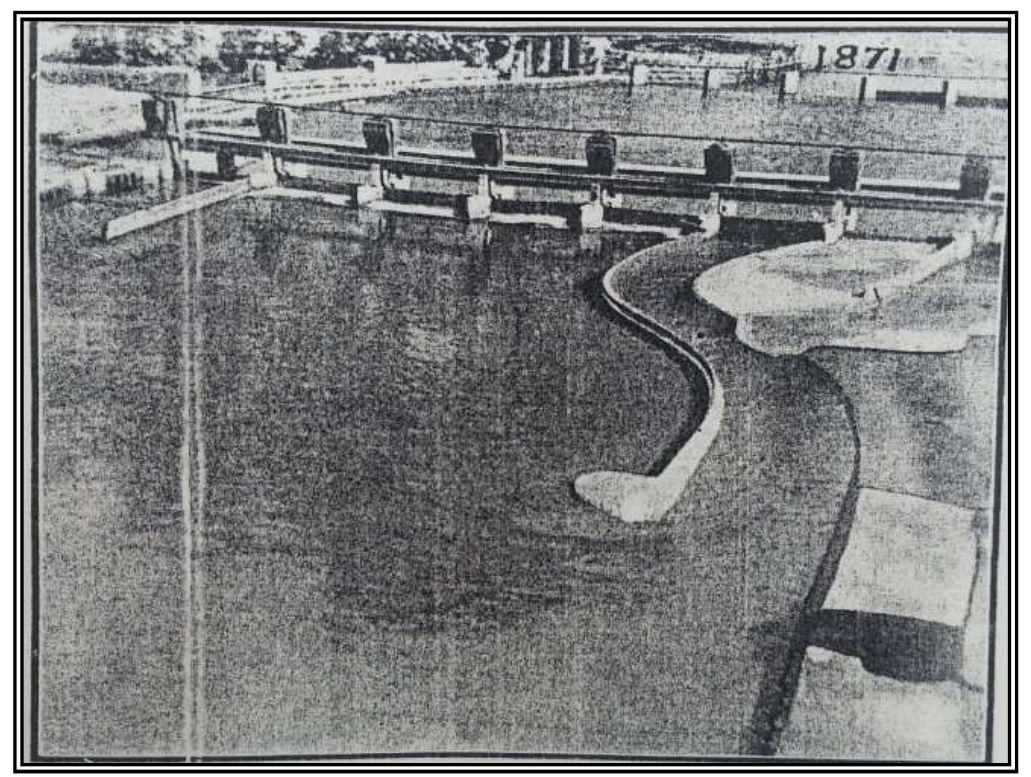

Figure 5. Shows 1/300 Scale model\& depth was 1/40 


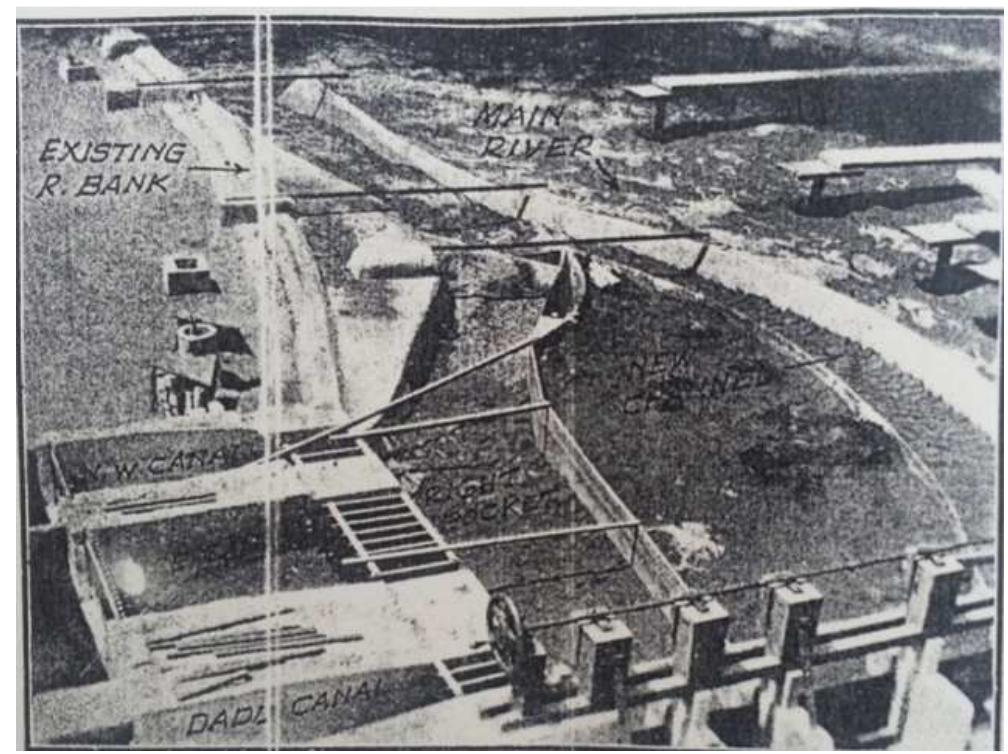

Figure 6. Shows 1/50 scale model.

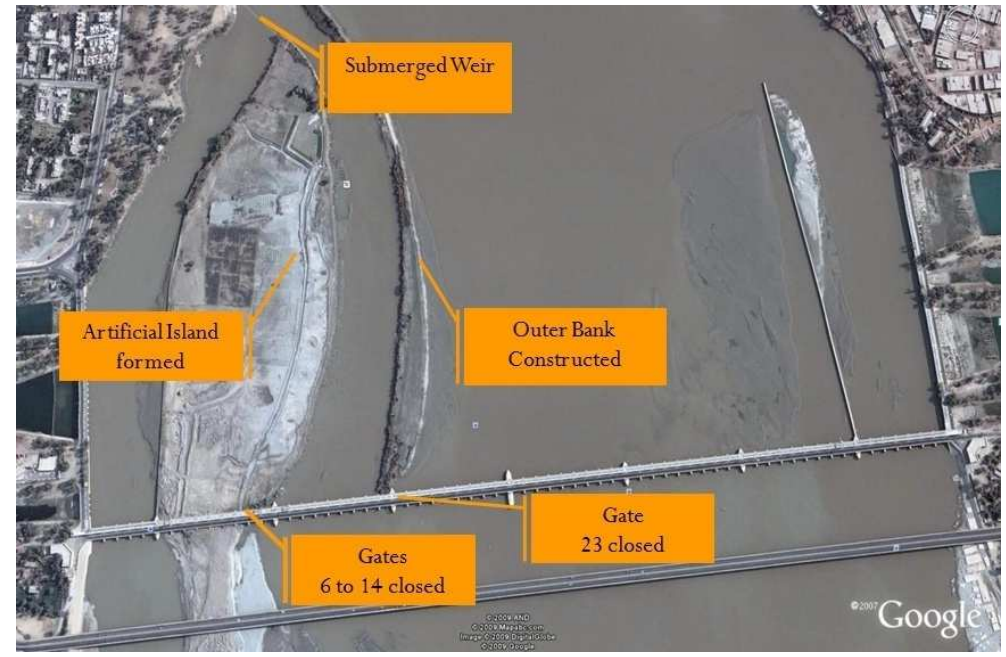

Figure 7. Shows (Google Image) Barrage model generation at site (Sukkur).

1) Year of Completion, 1942.

2) Design Discharge (revised), $0.9 \mathrm{~m}$ cusecs (25485 cumecs).

3) Design Water way, 3360 feet (1024 m).

4) Number of working bays, 56.

5) Cost of remedial works, Rs. 1.4 million.

\section{Impact on End Users}

1) $60 \%$ less cultivation in 2018 at SaifullahMagsi Branch Division at border of Sindh-Balochistan.

2) Main canals are silted up due to less velocity of water as compare to previous four years.

3) Forces were deployed to control law in order situation to avoid the water theft.

Table 2. Factors regarding to improving the carrying capacity of right bank canal system.

\begin{tabular}{lllllll}
\hline S NO & ITEMS & UNIT & N W CANAL & RICE CANAL & DADU CANAL & WARAH BRANCH \\
\hline 01 & Gross Commanded Area & ACRE & 1027085 & 547480 & 597464 & 316124 \\
02 & Cultivable Commanded Area & ACRE & 933093 & 480979 & 498682 & 312162 \\
03 & Final area of annual cultivation & ACRE & 761067 & 423802 & 425163 & 201500 \\
04 & Maximum discharge at Head & CUSEC & 9600 & 21500 & 5200 & 6200 \\
05 & Bed width at Head & FEET & 234.8 & 300 & 137 & 154 \\
\hline
\end{tabular}




\begin{tabular}{lllllll}
\hline S NO & ITEMS & UNIT & N W CANAL & RICE CANAL & DADU CANAL & WARAH BRANCH \\
\hline 06 & Full Supply Level at Head & R.L & 199.70 & 199.20 & 199.40 & 190.34 \\
07 & Design Bed Level & R.L & 183.70 & 182.2 & 184.40 & 177.61 \\
08 & Full Supply Depth & FEET & 16.0 & 17 & 15 & 12.70 \\
09 & Hydraulic Gradient & FEET & $1: 14000$ & $1: 10500$ & $1: 10000$ & $1: 11500$ \\
10 & Length of the Main Canal & MILE & 36.1 & 81.7 & 131.6 & 69.6 \\
11 & Number of Span & Number & $6(25 \mathrm{ft}$ each $)$ & $13(25 \mathrm{ft}$ each $)$ & $4(25 \mathrm{ft}$ each $)$ & $4(10 \mathrm{ft}$ each $)$ \\
12 & Crest of Head Regulator & R.L & 183.75 & 183.13 & 184.32 & 178.50 \\
\hline
\end{tabular}

Total Gross Commanded Area of RIGHT BANK CANALS 2488153 ACRES.

Total Cultivable Commanded Area of RIGHT BANK CANALS 2224916 ACRES.

REMARKS: Design Data of Right Bank Canals Figures were taken from Circle office Larkana, Pakistan.

Table 3. Shows impact on discharge of canals due to silt.

\begin{tabular}{llll}
\hline S No & Name of Canal & Design Discharge & Actual Discharge \\
\hline 01 & Rice Canal Head @ Sukkur Barrage & $21500 \mathrm{CS}$ & $11800 \mathrm{CS}$ \\
02 & Rice Canal @ Ruk Complex & $13500 \mathrm{CS}$ & $7400 \mathrm{CS}$ \\
03 & NW Canal @ Sukkur & $9600 \mathrm{CS}$ & $6700 \mathrm{CS}$ \\
04 & Warah Branch @ RD 83 of Rice Canal & $6200 \mathrm{CS}$ & $3400 \mathrm{CS}$ \\
\hline
\end{tabular}

\section{Suggestions}

1) Adding one span to North West Canal Head Regulator to Enhance the Discharge (that is not feasible).

2) It will be appropriate to enhance wier level to create pond of water in front of canals to serve both purposes, settling of coarser particles at head works and increasing the head to enforce water entry in canals.

3) Cleaning right pocket of sukkur barrage, so as to supply the adequate discharge in the right bank canals.

4) Maintaining the full supply depth of NW Canal and Rice Canal by Raising and Strengthening of Banks and De-silting work of canals if necessary.

5) De-silting will be the continueous process by silt dredgers at various places for maintaining discharge of warah Branch from RD 00 to 10 .

6) It is suggested to stabilize the sides of canals by stone pitching and cascades be provided at various places to increase the head.

\section{Results}

1) The N. W Canal and the Rice Canal have been silted up from RD 00 to 83.5 of both Canals.

2) Excessive silt entry in right bank canals due to above causes.

3) Computer based model results impact of water particle tracing from gates of barrage show path opposite to Right Bank Canals.

4) Sand dunes formed in front of head regulators inside right pocket.

5) Right Bank canals not able to take the design discharge

6) Reasons of silt deposition in canals is due to changed behavior of water flow in sukkur barrage, that causes huge deposition of silt at U/S right pocket of Barrage \& it's off-taking canals as well.

7) The excessive entry of silt in right side canals is much greater as compare to left side canals, which causes huge accumulation of silt in both canals viz Rice Canal and NW Canal, hence it has reduced the discharge capacity of both the Canals.

\section{Conclusion}

1) The reduction of discharge in Rice Canal Head @ Sukkur Barrage was 54\%.

2) The reduction of discharge in Rice Canal@Ruk Complex was $54.8 \%$.

3) The reduction of discharge in NW Canal @ Sukkur was $30 \%$.

4) The reduction of discharge inWarah Branch @ RD 83 of Rice Canal was $45 \%$.

5) $60 \%$ less cultivation in 2018 at SaifullahMagsi Branch Division at border of Sindh-Balochistan.

6) Satellite image based model shows negligible velocity to Right Pocket at Sukkur Barrage.

7) The problem is crucial, a team coprising seniors may be given this work as daunting task.

8) These canals are not only supplying water for irrigation but end area is total saline they are using this water for drinking and animals also.

\section{References}

[1] Global Warming "Amanda MacMillan" March 11-2016.

[2] Indus Basin Irrigation System of Pakistan. "Triple Bottom Line Magazine".

[3] Farhan Hussain Wagan \& Salim Khoso "WATER SHORTAGE; IT'S CAUSES, IMPACTS AND REMADIAL MEASURES" Conference: 6th International Civil Engineering Congress, At Karachi, Pakistan 2013.

[4] Z. Fuat TOPRAK " ideal velocity: A new concept for open channel flows" 2016 journal of water resources and hydraulic engineering (volume 5 Issue 3 pp116-121). 
[5] Tariq Usman Saeedand Taj Ali Khan "Impact of Water Losses and Maintenance of Canal Irrigation System on Agriculture (Case Study: Urmar Minor of Warsak Gravity Canal Pakistan).

[6] J. Puig Bargues, F. R Lamm "Effect of flushing velocity and flushing duration on sediment transport in microirrigation drip lines" 2013 American society of agricultural and biological engineers ISSN 2151-0032.

[7] Utah university digital commons @ USU.

[8] Khaled kheder, Afzal Ahmed and others "sediment transport investigation using three dimensional numerical modeling in a large canal, marala ravi link canal pakistan" 2014 ISSN 2229-5518 IJSER Volume 5 Issue 3.
[9] JO AQUIN DE ARAOZ "study of water flow velocities in irrigation canals in iraq and their methematical analysis" Bull Org mond sant 1962, 27 (99-123).

[10] Lateiro salvador de soura, Rapheal Muli Wam bua and others Febury 2019 www.mdpi.com/ journal/agriengineering.

[11] FAO. Irrigation Canal Lining. Irrigation and Drainage Paper No. 2. Rome, Italy: Foodand Agricultural Organization of the United Nations; 1977.

[12] Iqbal A. Immediate Solution to Water Crisis Daily Dawn, 17th 03. 2003. 